\title{
Institutions of social control in the Russian Federation: subjectivity case
}

\author{
Alexander Isacov, Alena Nikitina* \\ Russian Presidential Academy of National Economy and Public Administration, Yekaterinburg, \\ Russian Federation
}

\begin{abstract}
The article examines the analysis of the institution of social control in the Russian Federation and its subjectivity. The relevance of the study is due to the conceptual diversity and lack of scientific consensus regarding the concept of "social control". Also, this consensus is absent regarding other related concepts, which include "public control", "civil control", "people's control" and others. To solve this problem, a group of domestic sources that define these concepts are analyzed. It also analyzes the legal acts regulating social control in Russia. The role of the Public Chamber and the analysis of current scientific approaches to its consideration are considered in a separate block. In conclusion, it is concluded that there is a fundamental contradiction between expert assessments and the current legislative framework. This leads to the fact that civil initiatives in the field of social control can only be implemented in the forms proposed by the state.
\end{abstract}

\section{Introduction}

Trends in the socio-political development of the modern world are transforming relations between society and the state. The development of democratic institutions, the strengthening of the middle class and the complication of the social structure of society give rise to new challenges for public administration, adaptation to which becomes a criterion for the effectiveness of public administration.

Attempts at adaptation are of a dialectical nature. On the one hand, the state is trying to increase its presence in public life, insisting on the transfer of rights and freedoms to collective management, insisting on the absolute rationality of the state as the organizer of social life. Changes in this direction were vividly shown by the reaction of states to the pandemic of the new coronavirus infection, when the role of government intervention was forced to increase. On the other hand, the increasing complexity of the tasks solved by the state requires risk management. The method of risk management is to involve society in public administration processes, their openness, comprehensibility and accessibility. The demand for involvement on the part of society is contradictory: the growth in the number and quality of civil society institutions is proportional to the exacerbation of the problem of political absenteeism.

\footnotetext{
*Corresponding author: nikitina-as@,ranepa.ru
} 
Overcoming absenteeism and improving the quality of public administration, thus, become related problems, the solution of which is based on the plane of creating such institutions of civil society, with the help of which citizens would be involved in the process of governing the state, carried out this activity from an expert position and were interested in it. On the part of the state, this means the recognition of such institutions and full access to information on the adoption and implementation of state decisions.

Specifically, this logic is embedded in the system of public control created in the Russian Federation on the initiative of the President of the Russian Federation, voiced in the framework of the message to the Federal Assembly of the Russian Federation in 2004 ${ }^{1}$. The relevance of this system is emphasized in subsequent messages, for example, in 2012. This system is based on the creation of functional representation institutions in the domestic practice of public administration. The main institutes to be created were the Public Chambers, however, the essence of this system was not limited to them. Of greater importance was the definition of public control as a special sphere of government, in which citizens are involved in assessing and auditing the activities of state and municipal government bodies.

\section{Literature review}

The main function of creating these institutions was based, rather, not on the idea of improving the quality of public administration, but was part of the dominant model of legitimizing political power [1]. With the change in the model of legitimation, the attitude of the authorities to public control as such and to the participation of citizens in the process of public administration has changed. The emphasis changed from attracting selective citizens to the process of monitoring the activities of state authorities, to attracting citizens to participate in public administration. In fact, there has been a change in logic in the paradigm of citizen-state relations, when the basis of control is not control activity, but citizen's feedback based on interaction with the state.

So, if the logic of public control presupposed the creation of intermediary institutions between the citizen and the state, the main function of which was to synchronize the interests of the population and the state, in the process of which they acted as equivalent subjects with their own positions of power; now the state is seen as a structure that must adapt to the requirements of society in order to ensure the full realization of the rights and freedoms of citizens [2]. This is the main criterion for the efficiency of the entire state administration apparatus.

This logic maximizes the understanding of public control and requires a different terminological labeling. This need also arises because "due to the lack of separation into state and public control, the meaning of the considered concepts was sometimes distorted. As a result, public control was identified with such phenomena as social control and people's control "[3]. It is noted that all these elements are part of the general concept of democratic control, which unites both the efforts of society to control the activities of government bodies and state control over their bodies [4]. Such conceptual diversity does not allow for a clear scientific delimitation of concepts to determine the objects and subjects of control, institutions, as well as the forms and methods of its implementation. Conceptual systematization of these concepts will make it possible to understand and form the principles of scientific analysis to improve this area of public administration, optimize relations between society and the state.

\footnotetext{
${ }^{1}$ Message from the President of the Russian Federation V.V. Putin to the Federal Assembly of the Russian Federation of May 26, 2004 "On the most important national tasks" // Rossiyskaya Gazeta. 2004. No. 109. May 27.
} 
Conceptualization is not self-worth. Its conduct allows you to analyze the criteria for other significant issues of this topic. First, about the subjectivity of the institutions of social and public control, their effectiveness and potential. Secondly, about the forms and methods of involving citizens in the work of these institutions.

\section{Materials and methods}

The purpose of this study is to conceptualize the concepts of "social control" and "public control", as well as to differentiate them.

Important research tasks are:

Solving the question of the subjectivity of social control institutions in the Russian Federation: their identification, description of functions, principles of work, criteria of efficiency and potential.

Studying the prospects for digitalization of social control institutions and the potential effect of this activity on the effectiveness of the functioning of the public administration system as a whole.

The research is based on a combination of theoretical cross-disciplinary methods. To conceptualize the basic concepts, an analysis of current scientific literature related to the research topic is used. To resolve the issue of the legal nature of the phenomenon under study, the analysis of legislation is used. Both methods are used to form the managerial genesis of social control institutions.

To concretize the study, several heuristic hypotheses were put forward:

H1: The concept of social control is broader than social control and other concepts.

$\mathrm{H} 2$ : The scientific literature and legislation of the Russian Federation does not contain a clear definition of the concepts of social control and public control.

H3: Initiative for social control must come from citizens and public associations.

H4: The main institution of social control is the Public Chambers of different levels.

\section{Research results}

For the analysis with hypothesis H1, let us carry out a conceptual analysis of the basic concepts: "social control" and "public control", as well as "people's control", "civil control", "democratic control".

The first conceptualization of the concept of "social control" was made in the Soviet years. Then, it was understood as "a set of norms, institutions and relations aimed at ensuring people in accordance with the interests of the class and society as a whole through the activities of public institutions with the help of the state apparatus" [3]. This concept described the general theoretical basis for the exercise of popular control, which was understood as "state structures with elements of public participation of the most active citizens, representatives of various groups of society."

Accordingly, the concept of "social control" was a set of institutions of people's control. These institutions were created by the state, that is, "from above", and were aimed at joint activities of the state and society, aimed at monitoring the implementation of managerial decisions. The object of control was both violations of the law and discipline, and violators could be subject to various types of penalties, including disqualification [5].

The criterion for effective popular control, as it was understood in the Soviet period, was the collaboration of not two subjects, society and the state, but three - society, state and party. The modern political system does not admit such a formula; accordingly, this concept needs to be updated. Moreover, the implementation of social and popular control 
assumed that the criterion of the effectiveness of institutions is precisely the role of the state, while the tendencies of democratization are aimed at maximizing the public role.

In the 90s, the concept of "social control" was replaced by the concept of "democratic control", as well as "civil control". Democratic control presupposed a renewal of the concept, the actualization of the institutions of popular control within the framework of a democratic system. In particular, democratic control can either be understood as a set of all forms of public control over the activities of public authorities, which is a broad interpretation, or in a narrow sense as an identification "with the feedback function, through which the object (society) regulates the activities of the entity that controls it (the state ) "[6]. In this interpretation, the presence of democratic control is a criterion for the stability of the state, the possibility of reproduction of the political system. Civil control, on the other hand, is a synonymous concept and describes the creation of institutions for involving society in the process of monitoring the activities of state institutions within the framework of their actions being consistent with the spirit and essence of a democratic political regime [7-8], which is a criterion for building democracy as such [9]. The implementation of civil control can be carried out through civil initiatives [4].

A different view suggests that the concept of "civil control" is synonymous with the concept of "public control" [10, p. 13]. In turn, the concept of public control is widely covered in the Russian scientific literature. So, one of its definitions: "non-state control of public associations and individual citizens (ie subjects not endowed with state powers) over the activities of state authorities, local governments, and their officials" [11]. This definition emphasizes that the implementation of public control takes place outside the state and in the absence of state powers. The implementation of control lies on the shoulders, first of all, of public organizations and other subjects [12]. In this interpretation, the overwhelming majority of public control structures should be created "from below" at the initiative of citizens.

To determine the status of hypothesis H2, let us turn to the analysis of the current legislation. The concept of "public control" is the only one from the conceptual series that has a normative consolidation in the Russian Federation. So, according to the federal law "On the fundamentals of public control in the Russian Federation," it means: "the activities of subjects of public control, carried out in order to monitor the activities of public authorities, local authorities, state and municipal organizations, other bodies and organizations in accordance with federal laws, separate public powers, as well as for the purpose of public inspection, analysis and public assessment of the acts issued by them and the decisions taken ".

According to this definition, the normative logic of the institutions of public control presupposes their creation by the state, that is, "from above". In addition, the understanding of the objects of control is expanding: it includes not only public authorities, but also any institutions whose activities are carried out at the expense of public finances. The very activity of control is reduced to the process of observation, it is not assumed that there are any imperative powers.

The unifying opinion for these approaches is the position that public control is a description of the functional activities of institutions, while social control is a general concept that includes both institutions and their activities. This approach allows you to analyze not only the activities of structures provided for by law, but also special formats. For example, a special area of social control is combating corruption, which is not an object of public control [13]. It is noted that social control is aimed at assessing the rationality of spending the resources allocated by the state and is aimed at counteracting economic crime [14]. 
To test hypothesis H2, we will supplement the study with an analysis of the regulatory legal framework of social control in the Russian Federation. So, this issue is regulated by the following legal acts:

- Federal Law of April 4, 2005 No. 32-FZ "On the Public Chamber of the Russian Federation"; 2

- Federal Law No. 76-F3 of June 10, 2008 "On public control over ensuring human rights in places of detention and on assistance to persons in places of detention"; 3

- Federal Law of December 25, 2008 No. 273-F3 "On Combating Corruption"; 4

- Federal Law of February 9, 2009 No. 8-F3 "On providing access to information on the activities of state bodies and local self-government bodies"; 5

- Federal Law No. 212-FZ of July 21, 2014 "On the Foundations of Public Control in the Russian Federation"; 6

- Decree of the President of the Russian Federation of March 4, 2013 No. 183 "On consideration of public initiatives sent by citizens of the Russian Federation using the Internet resource"Russian Public Initiative"

This conglomerate of management acts assumes that the list of subjects of social control is open. However, the main subjects are established, which include: the Public Chamber of the Russian Federation, the Public Chambers of the constituent entities of the Russian Federation, the Public Chambers (Councils) of municipalities, Public Councils under the federal executive bodies and under the legislative (representative) and executive bodies of state power of the constituent entities of the Russian Federation. It should be noted that this list does not include public organizations, NGOs and other associations of citizens. This feature specifies the position of the hypothesis $\mathrm{H} 3$.

To analyze hypothesis H4, let us turn to the analysis of the Public Chamber of the Russian Federation. "Created as a platform for a broad dialogue, discussion of civil initiatives, the Public Chamber should become a place for examination of key government decisions of national importance, civil control of the state apparatus, including law enforcement agencies and special services" [15].

General management approaches to the analysis of the Public Chamber and its authentic functions within the framework of the Russian Federation's governance system are based on three main approaches:

First, the Public Chamber can be viewed as an institution of civil society [16]. Second, the Public Chamber can be viewed as a human rights institution [17-18]. Third, the Public Chamber can be viewed as an institution of representative democracy [19].

In accordance with this, the main goals of the Public Chamber's activities have been formulated. These goals include attracting active citizens and public associations to work, supporting and promoting the initiatives they promote. A special goal is to exercise public

\footnotetext{
${ }^{2}$ On the Public Chamber of the Russian Federation: federal. Law of 04.04.2005 No. 32-FZ (as amended on 11.06.2021).

${ }^{3}$ On public control over the provision of human rights in places of detention and on assistance to persons in places of forced detention: federal. Law of 06/10/2008 No. 76-FZ (as revised on 04/30/2021).

${ }^{4}$ Anti-Corruption Law: Federal. Law of December 25, 2008 No. 273-FZ (as amended on May 26, 2021).

${ }^{5}$ On providing access to information on the activities of state bodies and local self-government bodies: federal. Law of 09.20.2009 No. 273-FZ (as amended on 30.04.2021).

${ }^{6}$ On the fundamentals of public control in the Russian Federation: Federal Law No. 212-FZ dated July 21, 2014 (as amended on December 27, 2018).

${ }^{7}$ On consideration of public initiatives sent by citizens of the Russian Federation using the Internet resource "Russian Public Initiative: Decree of the President of the Russian Federation of 03/04/2013 No. 183-UP (as amended on 09/17/2020).
} 
control over the activities of executive and legislative bodies of different levels in the form of public expertise of draft regulations, as well as the development of recommendations for improving the quality of public administration.

In addition, the Public Chamber of the Russian Federation provides information, methodological and other support to public chambers of the constituent entities of the Russian Federation and public associations in order to establish and develop civil society. The Public Chamber monitors freedom of the media in the Russian Federation and international cooperation with public control bodies of other states and international organizations.

Thus, the main form of the Public Chamber's activity is to conduct a public examination of the draft regulatory legal acts adopted in the Russian Federation. Public examination implies an assessment of the administrative impact of this act for its compliance with the interests of Russian society or a particular social group. Public expertise is carried out through the creation of a working group of members of the Public Chamber; the subject of consideration can be both a regulatory legal act of any level, and sectoral development programs, or any other formalized practice of implementing state policy. At the same time, the following forms of expertise are used: involvement of experts, interpellation, sending members of the Public Chamber to work in committees and commissions of the Federal Assembly or to participate in meetings of federal executive bodies, where a draft normative legal act is considered, which is the object of public expertise. There is no single methodology for public expertise.

\section{Discussion and Conclusion}

H1: Research has shown that social control is indeed the broadest concept from the spectrum studied. Moreover, it is often used as a direct synonym for the term "public control". At the same time, it seems that social control characterizes the institution of control, while social control presupposes a functional essence, i.e. describes the subjects of control and the forms of their direct activity.

The concept of social control emerged during the Soviet era, but has been reinterpreted in post-Soviet times. Modern terminology is borrowed from commercial structures, where it is called public involvement in the assessment of the firm's performance [20]. The basis for assessment is not observation, supervision or participation in management, but direct feedback from contact with the structure. In this meaning, there is a conceptual similarity to the concept of "civil control", the essence of which also boils down to feedback through civil initiatives.

Accordingly, the main elements, and subsequently indicators of functioning, social control are: the presence of a special infrastructure, the presence of a culture of using this infrastructure by the citizens of the Russian Federation and the desire to participate in its development. In a closer examination, this situation can be viewed as an expanded understanding of the stories of Open Government and Electronic Governance [21].

$\mathrm{H} 2$ : There is indeed no conceptual consensus in the Russian Federation regarding the concept of "social audit". Moreover, it does not exist in relation to the concept of "public control". It is noted that social control in the Russian Federation is carried out by various public organizations operating on a non-commercial basis, often involved in the protection of the rights and freedoms of citizens [22]. The activities of such associations are qualified by the scientific community as social or public control. However, this qualification has no normative fixation.

However, there is a consensus on the definition of signs of social and public control. First, this control should be aimed at monitoring the activities of public authorities or their institutions. Secondly, this control is carried out without direct delegation of state powers, 
and decisions are not binding, but must be considered and taken into account by the authorities.

H3: The peculiarity of the functioning of social control in the Russian Federation is the fundamental methodological discrepancy between the scientific community and the current legislation. While the scientific community assumes that a natural consequence of the development of democracy and the emergence of civil society in the Russian Federation is the emergence of collective civic initiatives "from below", Russian legislation presupposes only state control from above in the person of public chambers and councils. "The state creates special conditions for them, while limiting independent subjects" [23].

Moreover, state initiatives for the implementation of public control can enter into direct opposition with public ones, suppress them, and neutralize them. This leads to the fact that "as a result, a quasi-legal structure is formed, based on the presumption of antagonism between public authorities and subjects of public control; in the future, this can lead to the nationalization of public control "[13].

H4: To date, there are no unified management approaches that determine the place and functionality of the Public Chamber of the Russian Federation. Various authors it refers to the institutions of civil society, representative democracy or legal protection of citizens. The current state of the chamber allows us to say that it contains in its functionality the elements of all these institutions. On the one hand, this expands its axiological meaning and potential functionality, and on the other hand, it reduces the actual possibility of influencing the control process. The legal nature of the chamber's activities is fully determined by federal legislation, but its actual activities are not regulated in an exhaustive way, and all decisions are exclusively advisory in nature. These features allow us to say that the Public payment of the Russian Federation can effectively perform its functions only by relying on its own derived vertical - the public chambers of the constituent entities of the Russian Federation.

The staffing of the chamber is provided by public organizations and associations. Their activities in the field of social control cannot be institutionalized except in the state institutions represented for this. This leads to a situation where independent social control is regarded as a threat to the state system. In such a situation, the basis for the effectiveness of the work of this institution is the absorption of public figures by state structures. This allows us to say that social control outside public chambers and councils is not normatively realizable.

Thus, the functioning of social control, its subjectivity, in the Russian Federation has a number of distinctive features. First of all, there is a fundamental gap between the expert understanding of this activity and the regulatory capacity provided by the state. Also, the presence of civic initiatives may conflict with the tasks of public control defined by the state. This leads to a situation when the actual customer of the control is the potential object of this control. This is both an indicator of the state's interest in the broad involvement of the population in the process of monitoring the adoption and implementation of state decisions, and the desire to maintain full state control over this process.

\section{Acknowledgments}

The article was prepared with the financial support of the grant of the President of the Russian Federation for state support of young Russian scientists - candidates of sciences MK-5062.2021.2 


\section{References}

1. K. A. Galitskaya, Changing the methods of legitimizing the power of the President of the Russian Federation in the period from 2012 to 2018, Management issues, 5 (54), 27-37 (2018)

2. M. V. Nepokupnaya, The content and structure of public control in the Russian Federation, Colloquium-journal, 3 (55), 70-72 (2020)

3. E. V. Matveeva, A. A. Mitin, A. A. Alagoz, Institute of Public Control in the Regional Political Space: Current State and Development Prospects, Bulletin of the Tomsk State University. Philosophy. Sociology. Political science, 43, 191-202 (2018)

4. M. Sh. Makhachieva, Public control in the system of civil initiatives, Colloquiumjournal, 27 (51), 178-179 (2019)

5. A. I. Lapshina, Public control and other institutions of public control over the activities of public authorities, Legal state: theory and practice, 2, 144-148 (2014)

6. P. Y Feldman, N. P. Khorkhordin, Russian model of democratic control: current state and prospects of evolution, Power, 8, 95-99 (2017)

7. Y. I. Isakova, Civil control in the formation of a democratic society, Bulletin of the Adyghe State University. Series 1: Regional studies: philosophy, history, sociology, jurisprudence, political science, cultural studies, 4, 217-224 (2012)

8. Y. I. Isakova, A. B. Melent'ev, Democratic structure and civil control in Russian society, Social and humanitarian knowledge, 11, 129-136 (2011)

9. E. V. Suryadnaya, Democratic values of modern Russian society as a condition for the formation of a system of civil control, Bulletin of VolSU. Series 4, History. Regional studies. International relationships, 1, 157-163 (2010)

10. A. A. Goncharov, Civilian control over government bodies (2010)

11. N. N. Kuleshova, On the current state of public control in Russia, Legal Science, 2 , 21-24 (2011)

12. E. V. Matveeva, A. A. Levin, Non-governmental organizations in modern Russia: on the issue of political and legal transformation, State power and local government, 9, 38-42 (2014)

13. T. Y. Khabrieva, Social control and anti-corruption, Journal of Foreign Legislation and Comparative Law, 4 (65), 5-10 (2017)

14. V. I. Poklad, Social control and economic crime, Russian Journal of Economics and Law, 4 (28), 252-258 (2013)

15. A. A. Panov, The Public Chamber of the Russian Federation as a New Subject of Civil Society, Law and State, 6, 22-30 (2005)

16. I. A. Kuznetsov, Public chamber as an institution of civil society, Bulletin of BIST. Series "Jurisprudence, 2, 73-78 (2015)

17. E. A. Ogneva, Public chamber as a human rights institution in the system of public control in modern Russia, Central Russian Bulletin of Social Sciences, 1, 146-151 (2014)

18. Z. N. Koshkina, Public Chamber of the Russian Federation as an institution for the protection of the rights and freedoms of citizens, Problems in Russian legislation. Legal journal, 1, 21-23 (2013)

19. V. N. Rudenko, Deliberative democracy in the axiology of human rights protection, Antinomies, 4, 115-127 (2017) 
20. M. N. Tolchinskaya, Russian model of social audit, UEPS, 2, 74-76 (2017)

21. A. V. Markeeva, O. V. Gavrilenko, Digital platform as a new economic actor and a new instance of social control, Moscow University Bulletin. Series 7. Philosophy, 5, 29-48. (2019)

22. O. V. Makarova, Public control over the observance of openness of information about the activities of public authorities, Journal of Russian law, 7 (247), 54-62 (2017)

23. O. E. Starodubova, Public control: legal support, Journal of Russian law, 2 (194), 130$136(2013)$ 